\title{
Contrasting effects of an invasive ant on a native and an invasive plant
}

\author{
Lori Lach · Chadwick V. Tillberg • \\ Andrew V. Suarez
}

Received: 6 October 2009/ Accepted: 12 January 2010/Published online: 29 January 2010

(C) The Author(s) 2010. This article is published with open access at Springerlink.com

\begin{abstract}
When invasive species establish in new environments, they may disrupt existing or create new interactions with resident species. Understanding of the functioning of invaded ecosystems will benefit from careful investigation of resulting species-level interactions. We manipulated ant visitation to compare how invasive ant mutualisms affect two common plants, one native and one invasive, on a subtropical Indian Ocean island. Technomyrmex albipes, an introduced species, was the most common and abundant ant visitor to the plants. T. albipes were attracted to extrafloral nectaries on the invasive tree
\end{abstract}

L. Lach · C. V. Tillberg · A. V. Suarez

School of Integrative Biology, Departments

of Entomology and Animal Biology, University

of Illinois, 320 Morrill Hall, 505 S. Goodwin Ave,

Urbana, IL 61801, USA

L. Lach

Mauritian Wildlife Foundation, Grannum Road,

Vacoas, Mauritius

Present Address:

L. Lach $(\bowtie)$

School of Plant Biology, M090, The University

of Western Australia, 35 Stirling Hwy., Crawley,

WA 6009, Australia

e-mail: lorilach@cyllene.uwa.edu.au

Present Address:

C. V. Tillberg

Department of Biology, Linfield College,

McMinnville, OR 97128, USA
(Leucaena leucocephala) and deterred the plant's primary herbivore, the Leucaena psyllid (Heteropsylla cubana). Ant exclusion from L. leucocephala resulted in decreased plant growth and seed production by $22 \%$ and $35 \%$, respectively. In contrast, on the native shrub (Scaevola taccada), T. albipes frequently tended sap-sucking hemipterans, and ant exclusion resulted in 30\% and 23\% increases in growth and fruit production, respectively. Stable isotope analysis confirmed the more predacious and herbivorous diets of T. albipes on the invasive and native plants, respectively. Thus the ants' interactions protect the invasive plant from its main herbivore while also exacerbating the effects of herbivores on the native plant. Ultimately, the negative effects on the native plant and positive effects on the invasive plant may work in concert to facilitate invasion by the invasive plant. Our findings underscore the importance of investigating facilitative interactions in a community context and the multiple and diverse interactions shaping novel ecosystems.

Keywords Ant mutualisms - Extrafloral nectaries · Enemy release $\cdot$ Herbivory $\cdot$ Honeydew .

Trophic position

\section{Introduction}

Species interactions are key components of communities and their strength and number can influence a 
wide variety of ecological characteristics including biological diversity and a species' abundance and distribution (Bascompte and Jordano 2007; Boucher et al. 1982; Bronstein 1994; Bruno et al. 2003). The establishment of invasive species can potentially change ecosystem function by either disrupting existing or creating novel interactions among resident species (Hobbs et al. 2006). Elucidating the nature of interactions in which invasive and native species take part can shed light on mechanisms of success and impacts of invasive species in their new ecosystems. While competition and predation have dominated research on biological invasions, it is apparent that positive interactions among species also influence invasion success and impact (Grosholz 2005; O'Dowd et al. 2003).

Interactions that are mutually beneficial to the participants can either encourage or repel introduced species. Facilitative and mutualistic interactions among introduced species can lead to "invasional meltdown": larger or more accelerated ecological impacts than those expected if the invaders involved did not synergistically interact with one another (Simberloff 2006; Simberloff and Von Holle 1999). In California, for example, the introduced European green crab indirectly facilitates an introduced clam by preferentially preying on a native clam that out competes the non-native clam in the absence of the crab (Grosholz 2005). Introduced and native species may also positively interact (Chamberlain and Schlising 2008; Thieltges 2005). Perhaps the worst-case scenario is one in which an invasive species negatively affects native species and positively affects non-native species.

In the search for carbohydrate-rich resources to fuel their workers, ants often have mutually positive interactions with plants or other insects. Ants may be attracted by extrafloral nectaries (EFNs) and may benefit plants by deterring herbivores (Koptur 1991). However, they also tend honeydew-producing hemipterans, benefiting the bugs by deterring their predators and/or parasites. These ant-trophobiont mutualisms often persist at the expense of the plant (e.g., O'Dowd et al. 2003), but sometimes to its benefit if the ants also deter more harmful herbivores (Styrsky and Eubanks 2007). In a community of native and invasive plants hosting an array of carbohydrate-rich resources, the dietary choices made by ants could conceivably facilitate plant invasion by displacing herbivores from invasive plants, in effect releasing them from natural enemies. Alternatively, ants may promote biotic resistance to plant invasions if native plants are protected and herbivory on invasive plants is exacerbated.

We experimentally manipulated visitation rates of ants to an introduced EFN-bearing tree from Central America (Leucaena leucocephala, Fabaceae) and a common native shrub (Scaevola taccada, Goodenaciae) on an islet off of Mauritius (Indian Ocean) to examine the consequences of novel interactions among native and introduced species. We hypothesized that if the plants hosted honeydew-producing insects, excluding ants would result in increased plant growth and reproduction. However, if other more harmful herbivores were present, excluding ants would yield decreases in plant growth and reproduction. We also hypothesized that the ants' calculated trophic levels would reflect their interactions with herbivores on the plants.

\section{Methods}

Site and species descriptions

Ant-manipulation experiments were conducted on Ile aux Aigrettes, a 26 ha coralline limestone islet nature reserve $700 \mathrm{~m}$ from mainland Mauritius $\left(20^{\circ} 25^{\prime} \mathrm{S}\right.$, $57^{\circ} 44^{\prime} \mathrm{E}$ ) in the subtropics. For a description of the island's history and vegetation types see Parnell et al. (1989). The islet hosts $12-15$ species of epigaeic ants, only two of which are likely native. Technomyrmex albipes, is numerically dominant on the islet and has been present in the country since at least 1942 (Donisthorpe 1946). It is a widespread tramp ant, recently distinguished from $T$. dificilis and T. vitiensis (Bolton 2007), and presumed native to east Asia (B. Fisher, pers. comm.). We chose an introduced tree (Leucaena leucocaphala) and a native shrub (Scaevola taccada) for our experiments because they were common, had obvious interactions with ants, and allowed for a comparison between species that are ecologically important in Mauritius. L. leucocephala has been named one of the world's hundred worst invasive species (Lowe et al. 2004). Though it has been widely introduced for tropical forage production, it can form dense monotypic stands and is considered a weed in 20 countries on 
five continents (Hughes 2006). It was introduced to tropical Africa during the 1800s (Hollis 1992). The tree has EFNs that are visited by ants. The Leucaena psyllid, Heteropsylla cubana, (Hemiptera: Psyllidae) reached Mauritius in 1991; it is a major herbivore of the tree in its native range and in much of its introduced range, causing defoliation and dieback (Hollis 1992). The native $S$. taccada is frequently used in restoration efforts on subtropical islands. It hosts several species of pan-tropical sap-sucking herbivores.

Mean temperatures in southeastern Mauritius range from 17 to $25^{\circ} \mathrm{C}$ in the winter months of June-August and from 18 to $30^{\circ} \mathrm{C}$ the rest of the year. Average annual rainfall is $1,700 \mathrm{~mm}$ with most falling during the cyclone season from December to May. Average humidity is $77-83 \%$ year-round (Mauritian Meteorological Services 2005).

\section{Ant exclusion experiments}

For each plant species, five mostly monotypic stands were selected from around the islet. Each stand was at least $50 \mathrm{~m}$ from the nearest stand with the same species. At each L. leucocephala stand the first 20 trees that had a pair of branches that were a comparable distance from the ground and had a similar number and condition of rachises were marked. These conditions were met approximately every third tree. One of the pair was randomly chosen for ant exclusion. On $S$. taccada, up to 15 shrubs per stand that had four branches matched for number of leaves, hemipteran load, and distance from the ground were selected. Approximately every fourth shrub met these conditions. A $2 \times 2$ factorial experiment on the S. taccada branches was performed with treatments (1) ant exclusion and (2) one-time washing with soapy water to remove hemipterans. The washing was done to determine how long it takes for hemipteran populations to colonize $S$. taccada in the presence and absence of ants. Ant barriers on both tree species consisted of a $2 \mathrm{~cm}$ wide strip of cotton fiber covered with plastic wrap, dark plastic (so stuck insects would not attract native birds) and coated with Tanglefoot ${ }^{\circledR}$. Barriers were applied below the lowest rachis on $L$. leucocephala branches and $15 \mathrm{~cm}$ below the end of the branch on $S$. taccada. Experiments began in August and September 2004 for
L. leucocephala, and S. taccada, respectively, and continued for 8 months. We maintained barriers weekly, and checked branches for ants, other arthropods, and vegetative growth every $2-3$ weeks during the cooler part of the day (0600-1100). Any ants found on the branches with barriers were immediately removed. Since psyllids were often extremely abundant and difficult to quantify, the number of rachises on the experimental branches on which psyllid adults, eggs, or nymphs were present was counted. Other insects on both plants were counted individually per leaf or rachis during each observation period. In addition, on L. leucocephala we collected seedpods as they matured and counted their seeds, and on S. taccada, we marked and counted mature fruits as they appeared. Plants that were damaged by storms, or on which barriers were repeatedly breached, were excluded from analyses yielding sample sizes of 77 L. leucocephala trees and $56 \mathrm{~S}$. taccada shrubs.

With the exception of trophic position comparisons (see below), all statistical analyses were conducted using repeated measures mixed models in SAS 9.1. Mixed models account for non-independence of observations over time and on the same tree and hence every observation is a unit of replication. We used the GLMMIX macro, which uses a log-link function to account for overdispersed Poisson distributed data and returns log-transformed least-square means (SAS Institute 1988). For each plant species, herbivore load, vegetative growth, and reproduction were analyzed. For L. leucocephala, herbivore load was the proportion of rachises with psyllids during each observation, vegetative growth was the net number of rachises added during the experiment standardized by the number of rachises on the branch at the beginning of the experiment, and reproduction was the number of seeds produced that appeared viable (i.e., were not shrivelled or abnormally small). For S. taccada, herbivore load was the mean total number of sap-sucking hemipterans/leaf for each observation, vegetative growth was the net leaf gain observed since the previous observation, and reproduction was the number of fruits added since the previous observation. To give time for the treatments to have an effect, growth and reproduction variables were analyzed starting 1 month after treatment. Since the washing experiment on $S$. taccada had no effect on net leaf growth or fruit production, washed and unwashed treatments were grouped for analysis of 
these variables. Back-transformed least-square means are presented in the figures.

\section{Stable isotope analysis}

Stable isotope analysis can be a powerful tool for elucidating dietary inputs and the relative trophic position of ants in food webs (Blüthgen et al. 2003; Davidson et al. 2003; Mooney and Tillberg 2005). We collected samples from six L. leucocephala and five $S$. taccada plants. Samples of the most commonly encountered ant (see Results), Technomyrmex albipes, from each plant consisted of ten workers collected from the surface of each plant. Due to their minute size, these ants were subsequently combined into one sample for each plant species for analysis. We also collected 15-20 individuals of the most common hemipteran species present (Parasaessetia nigra (Hemiptera: Coccidae) on L. leucocephala and Icerya seychellarum (Hemiptera: Margarodidae) on S. taccada). Hemipteran samples taken from each plant were combined to yield a massive enough sample. Predator samples from each plant include spiders and predacious beetles (Coccinellidae).

All samples were freeze-killed and dried in an oven at $50^{\circ} \mathrm{C}$ for 2 days. Samples were then stored in airtight containers with desiccant until processing. All arthropod samples were weighed into foil capsules for a sample mass of about 1,500 $\mu \mathrm{g}$. Plant leaves were first lyophilized and ground to a fine powder and then about 3,000 $\mu \mathrm{g}$ of plant material was placed into each foil capsule. Samples were analyzed at the University of California, Davis, Stable Isotope Facility.

\section{Calculating Technomyrmex albipes trophic position}

Plant-based, first trophic level resources (honeydew, extrafloral nectar) and third trophic level predators (such as spiders) represent opposite ends of the spectrum of the dietary resources available to ants foraging in the focal plants. Using $\delta^{15} \mathrm{~N}$ values for organisms of known trophic position, we calculated trophic position for each replicate of $T$. albipes on L. leucocephala and S. taccada by modifying Post's equation (Post 2007) where the proportion of dietary inputs from the first $\left(\rho_{1}\right)$ and second $\left(\rho_{2}\right)$ sources is calculated as:

$$
\begin{aligned}
\rho_{1}= & {\left[\delta^{15} \mathrm{~N}_{\text {T.albipes }}-\delta^{15} \mathrm{~N}_{(2)}-\Delta_{\mathrm{N}^{\prime \prime}}\right] } \\
& /\left\{\left[\delta^{15} \mathrm{~N}_{\text {T.albipes }}-\delta^{15} \mathrm{~N}_{(2)}-\Delta_{\mathrm{N}^{\prime \prime}}\right]\right. \\
& \left.+\delta^{15} \mathrm{~N}_{(1)}+\Delta_{\mathrm{N}^{\prime}}-\delta^{15} \mathrm{~N}_{\text {T.albipes }}\right\}
\end{aligned}
$$

$\rho_{2}=1-\rho_{1}$.

$\delta^{15} \mathrm{~N}_{(1)}$ and $\delta^{15} \mathrm{~N}_{(2)}$ are the values for potential dietary resources of known trophic position-plants and spiders respectively in this case. As in other systems (McCutchan et al. 2003), enrichment between the first and second trophic levels varied in this system. Therefore, we calculated separate enrichment factors for herbivorous and predacious trophic interactions. We established $\Delta_{\mathrm{N}^{\prime}}$ by comparing mean enrichment from plants to herbivores for the whole system; this resulted in a $\Delta_{\mathrm{N}^{\prime}}=1.0 \%$. For predacious trophic interactions, we compared mean $\delta^{15} \mathrm{~N}$ of herbivores to mean $\delta^{15} \mathrm{~N}$ of spiders in this system, which yielded $\Delta_{\mathrm{N}^{\prime \prime}}=3.1 \%$.

Finally, trophic position of T. albipes was calculated as:

$\mathrm{TP}_{\text {T. albipes }}=\mathrm{TP}_{\text {spiders }}+1-\left(\mathrm{TP}_{\text {spiders }}-\mathrm{TP}_{\text {plants }}\right) \rho_{1}$

\section{Results}

Technomyrmex albipes, was the most common ant visitor, accounting for over $97 \%$ of all ants observed on each of our tree species. T. albipes were observed to visit over a third of $L$. leucocephala and nearly three quarters of $S$. taccada branches without barriers (Table 1). Observed visitation by other non-native ants and the native ant, Camponotus grandidieri, was rare (Table 1). We suspect that wind, and leaves and other debris dropping onto our experimental branches account for the presence of ants on some antexcluded branches (Table 1). However, ant abundance on these branches was always much lower than on branches without barriers (Fig. 1; Table 1) because ants were not able to cross the barriers and recruit other workers.

The Leucaena psyllid was the most frequently encountered herbivore on L. leucocephala, occurring on $90 \%$ of experimental trees, and during about a quarter of observations (Table 1). T. albipes were sometimes seen carrying $H$. cubana nymphs away, but were never seen imbibing their excreted sap. In contrast, on $S$. taccada, the pan-tropical scale insects $P$. nigra and $I$. seychellarum were the main 
Table 1 Frequency (percent of observations) of ant and herbivore sightings by plant species and treatment

\begin{tabular}{|c|c|c|c|c|c|}
\hline & \multirow[t]{2}{*}{ Status } & \multicolumn{2}{|c|}{ L. leucocephala $n=77$ trees } & \multicolumn{2}{|c|}{ S. taccada $n=54$ shrubs } \\
\hline & & Ants+ & Ants- & Ants+ & Ants- \\
\hline \multicolumn{6}{|l|}{ Ants } \\
\hline T. albipes & Non-native & 36.0 & 13.1 & 73.9 & 37.2 \\
\hline A. gracilipes & Non-native & 1.78 & 0.09 & 5.09 & 0.07 \\
\hline P. megacephala & Non-native & 0.00 & 0.09 & 0.35 & 0.07 \\
\hline C. grandidieri & Native & 0.18 & 0.18 & 0.84 & 0.07 \\
\hline Other ants & Non-native & 0.72 & 0.00 & 2.72 & 0.70 \\
\hline \multicolumn{6}{|l|}{ Herbivores } \\
\hline H. cubana & Non-native & 23.6 & 28.6 & 0 & 0 \\
\hline P. nigra & Pan-tropical & 4.97 & 2.34 & 36.1 & 21.4 \\
\hline I. seychellarum & Pan-tropical & 0.27 & 0.0 & 39.3 & 20.3 \\
\hline
\end{tabular}

Ants $+=$ ant-allowed treatment, Ants $-=$ ant-excluded treatment
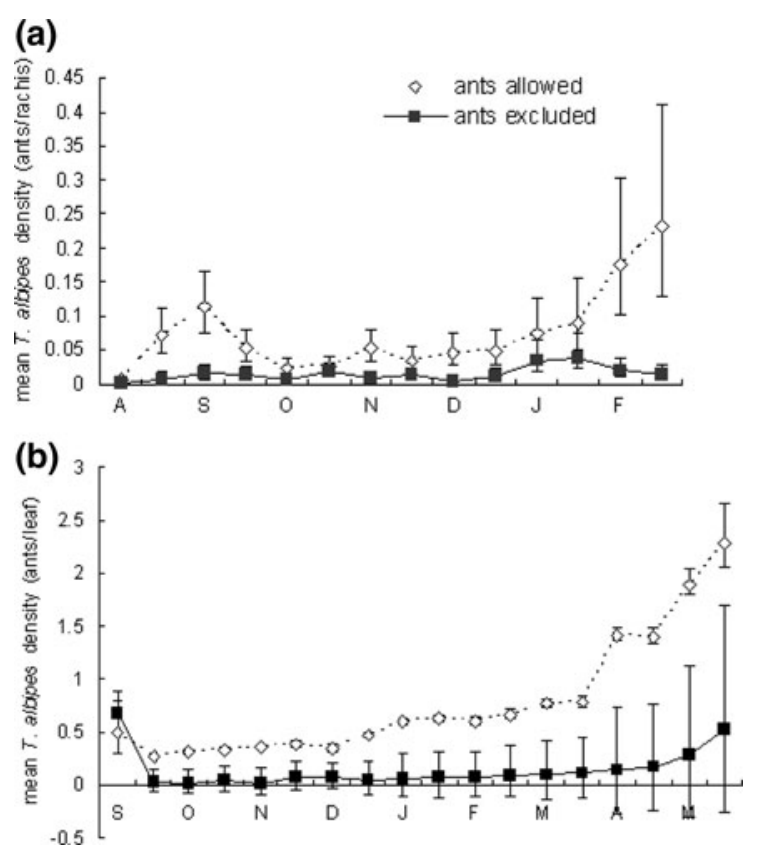

Fig. 1 Densities (mean $\pm \mathrm{SE}$ ) of $T$. albipes on ant-allowed and ant-excluded branches for a the invasive L. leucocephala tree and $\mathbf{b}$ the native $S$. taccada shrub over time. The first observation in each graph is prior to application of the ant exclusion treatment. See Table 2 for results of the ANOVA of post-treatment observations

herbivores (Table 1), occurring on all of the experimental trees, and frequently tended by $T$. albipes. Scale insects occurred much less frequently on L. leucocephala (Table 1). Ant exclusion resulted in a slight increase in the proportion of L. leucocephala rachises with psyllids, (Fig. 2a; Table 2) in contrast to the marked decline in densities of sap-sucking insects on ant-excluded branches compared to antallowed branches on the native $S$. taccada (Fig. 2b; Table 2). Within 12 weeks, washed branches with ants had the same hemipteran load as unwashed branches with ants, and within 4 weeks unwashed branches without ants had the same hemipteran load as washed branches without ants (Fig. 2b).

Plant growth and reproduction were also affected by ant exclusion on S. taccada and on L. leucocephala when scale insects were absent. Although the overall analysis of growth on the invasive L. leucocephala yielded no significant effects of ant exclusion or scale insect presence (Table 2), in the absence of scale insects, vegetative growth decreased by $22.0 \%$ when ants were excluded $(t=2.16, d f=68, P=0.0346$; Fig. 3a), but there was no significant difference between ant-excluded and ant-allowed branches when scale insects were present $(t=0.60, d f=68$, $P=0.55$; Fig. 4 a). Seed output on $L$. leucocephala was also related to scale insect presence (Table 2). In the absence of scales, ant exclusion decreased seed output by $35.0 \%(t=2.31, d f=68, P=0.0241)$; when $P$. nigra was present, ant exclusion resulted in $52.5 \%$ higher seed set, though this difference was not quite statistically significant $(t=-1.77, d f=68$, $P=0.0817$; Fig. 4a). In contrast, on the native S. taccada, ant exclusion resulted in a $30 \%$ increase in vegetative growth and $23 \%$ increase in fruit production (Figs. 3b, 4b; Table 2). 

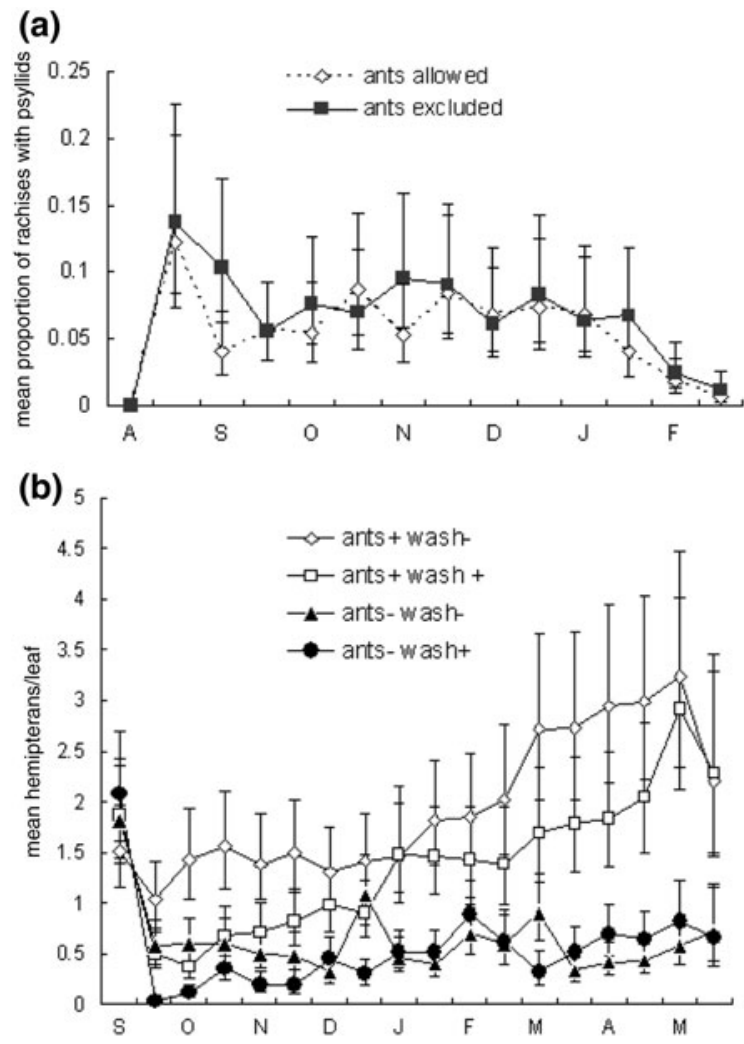

Fig. 2 Effects of ant exclusion on herbivores (mean \pm SE) for a the invasive L. leucocephala tree and $\mathbf{b}$ the native $S$. taccada shrub over time. The first observation in each graph is prior to application of the ant exclusion treatment. See Table 2 for results of the ANOVA of post-treatment observations

Consistent with the results of the ant-exclusion experiments, stable isotope analysis revealed that the calculated trophic position for T. albipes was higher on L. leucocephala (mean \pm standard error: $2.46 \pm$ 0.05 ) than on $S$. taccada $(2.14 \pm 0.12$ ), (Wilcoxon test $Z=-2.09, P=0.0367$ ).

\section{Discussion}

Our results reveal multiple interactions in which the invasive ant, T. albipes, takes part in this ecosystem, and how its trophic position reflects the effects it has on invasive and native plants via interactions with their herbivores. On the invasive L. leucocephala, T. albipes is more predacious; it attacks the Leucaena psyllid and its presence results in increased growth and seed production for the tree. The presence of honeydew-producing scale insects can offset the benefits of the psyllid displacement, but most L. leucocephala plants do not host scale insects. In contrast, on the native $S$. taccada, T. albipes is more herbivorous; it obtains honeydew from sap-sucking hemipterans, increasing their density and causing diminished growth and reproductive output.

Our paired-branch design allowed us to obtain accurate data on growth and seed production in relation to the numbers and species of herbivores and ants that would not have been feasible at a wholeplant level. The paired branch design also eliminated potentially confounding inter-plant variation of several variables such as tree age, resource availability, growth, and exposure to ants and herbivores. Moreover, excluding ants at the whole-plant level for these thicket-producing plants would have required severe pruning. However, a caveat of experimentation at the branch level is the possibility that the observed growth and reproduction responses do not scale up to the whole-plant level. For example, plants may integrate responses to herbivory, reallocating resources responsible for growth and reproduction away from highly herbivorized branches to those with little or no herbivory, thus amplifying the difference in response between the two. The question of whether plants have modular or integrated responses to herbivory has been investigated repeatedly and remains uncertain (Kaitaniemi and Ruohomaki 2006); conclusions have varied depending on plant species, patterns of herbivory damage, herbivore behavior, and the specific plant responses measured (Kaitaniemi and Ruohomaki 2006; Marshall 1989).

It is not unusual for ants to have different effects on different plant species depending on the mix and characteristics of herbivores and predators present (e.g., Sipura 2002). Whether or not the contrasts in plant outcomes mediated by the ant-herbivore interactions seen here-positive effects for the invasive plant and negative effects for the native plant-are common where carbohydrate-seeking invasive ants have established would require at least two conditions to be met. First, invasive plants would have to be susceptible to injurious herbivores and have some means of attracting ants to displace them. Whether invasive plants are more likely to have EFNs, or other means of attracting ant-guards is unknown. We know of only one extant native species in our study system, Gagnebina pterocarpa (Leguminosae) that has EFNs. Its conservation status is 'vulnerable' (Atkinson and 
Table $2 F$ statistics from type III analysis of variance

\begin{tabular}{|c|c|c|c|}
\hline Response variables and sources of variation & $d f$ & $F$ & $P$ \\
\hline \multicolumn{4}{|l|}{ 1. Ant densities } \\
\hline \multicolumn{4}{|l|}{ L. leucocephala } \\
\hline Ant exclusion & 1,1494 & 92.2 & $<0.0001$ \\
\hline Time & 12,1494 & 2.73 & 0.0012 \\
\hline Ant exclusion $*$ time & 12,1494 & 2.45 & 0.0037 \\
\hline \multicolumn{4}{|l|}{ S. taccada } \\
\hline Ant exclusion & 1,2629 & 260 & $<0.0001$ \\
\hline Time & 17,2629 & 5.13 & $<0.0001$ \\
\hline Ant exclusion $*$ time & 17,2629 & 1.05 & 0.40 \\
\hline \multicolumn{4}{|l|}{ 2. Herbivore load } \\
\hline \multicolumn{4}{|c|}{ L. leucocephala proportion of rachises with psyllids } \\
\hline Ant exclusion & 1,1494 & 5.47 & 0.0195 \\
\hline Time & 12,1494 & 4.99 & $<0.0001$ \\
\hline Ant exclusion $*$ time & 12,1494 & 1.22 & 0.26 \\
\hline \multicolumn{4}{|l|}{ S. taccada mean hemipteran density } \\
\hline Ant exclusion & 1,2595 & 137.2 & $<0.0001$ \\
\hline Washing & 1,2595 & 28.89 & $<0.0001$ \\
\hline Time & 17,2595 & 2.03 & 0.0074 \\
\hline Ant exclusion $*$ time & 17,2595 & 1.66 & 0.0430 \\
\hline Washing $*$ time & 15,2595 & 4.89 & $<0.0001$ \\
\hline Ant exclusion $*$ washing & 1,2595 & 0.04 & 0.85 \\
\hline Ant exclusion $*$ washing $*$ time & 17,2595 & 1.69 & 0.0377 \\
\hline \multicolumn{4}{|l|}{ 3. Vegetative growth } \\
\hline \multicolumn{4}{|l|}{ L. leucocephala net rachises added } \\
\hline Ant exclusion & 1,68 & 2.89 & 0.0939 \\
\hline P. nigra presence & 1,68 & 1.20 & 0.28 \\
\hline Ant exclusion $* P$. nigra & 1,68 & 0.21 & 0.65 \\
\hline \multicolumn{4}{|l|}{ S. taccada net leaf gain } \\
\hline Ant exclusion & 1,2361 & 7.13 & 0.0076 \\
\hline \multicolumn{4}{|l|}{ 4. Reproductive output } \\
\hline \multicolumn{4}{|l|}{ L. leucocephala seeds } \\
\hline Ant exclusion & 1,68 & 0.00 & 0.97 \\
\hline P. nigra presence & 1,68 & 0.62 & 0.43 \\
\hline Ant exclusion $* P$. nigra & 1,68 & 6.75 & 0.0115 \\
\hline \multicolumn{4}{|l|}{ S. taccada fruits } \\
\hline Ant exclusion & 1,2362 & 7.42 & 0.0065 \\
\hline
\end{tabular}

Sevathian 2005) and it occurs as rare, scattered individuals on Ile aux Aigrettes (L. Lach, personal observation). Many species of invasive ants are attracted to EFNs and subsequently displace herbivores (Lach and Hooper-Bùi 2010; Ness and Bronstein 2004).

The second condition that would need to be met for the findings here to be a widely occurring pattern is that native plants would have to be more likely than invasive plants to suffer from negative effects of anttrophobiont mutualisms. This would require that the trophobionts be injurious, invasive ant-tending result in increased herbivory by trophobionts, and the ants not deter other harmful herbivores. Though there has been recent work investigating the susceptibility of introduced and native plants to herbivores (e.g., Dietz 


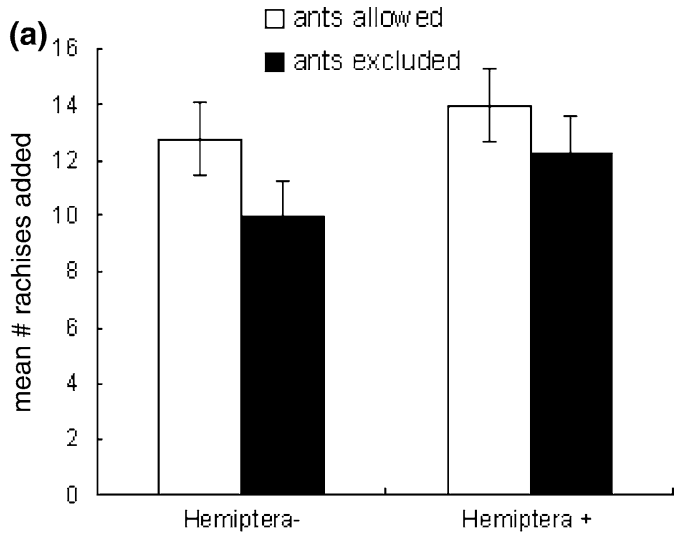

(b)

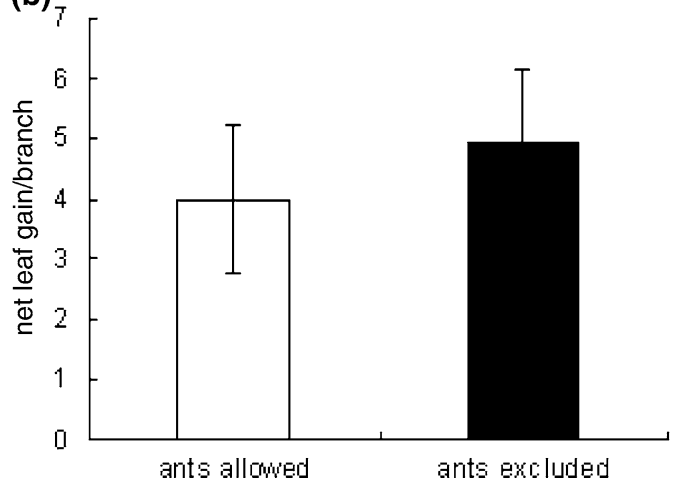

Fig. 3 Effects of ant exclusion on vegetative growth (mean $\pm \mathrm{SE}$ ) for a $L$. leucocephala, and b $S$. taccada. See Table 2 for results of the ANOVA

et al. 2004; Parker et al. 2006), we are not aware of any studies exploring the relative susceptibility of native and introduced plants to ant-tended herbivores. In our study, trophobionts were much less prevalent on the invasive L. leucocephala than on the native $S$. taccada and other native plant species on the island. For example, out of 40 randomly selected 'critically endangered' Gastonia mauritiana (Araleaceae) and Diospyros eggretarum (Ebenaceae) trees on the island, there were only 1 and 3 , respectively, in which we did not find scale insects (L. Lach unpublished data). Tending of trophobionts by invasive ants often results in increased abundance of these insects, in many cases with subsequent negative effects for the plant (Lach and Hooper-Bùi 2010; O'Dowd et al. 2003). However, ants may benefit plants if they deter other more harmful herbivores (Styrsky and Eubanks 2007). For S. taccada in our study, other herbivores were rarely observed and the scales' decline as a result of ant exclusion led to
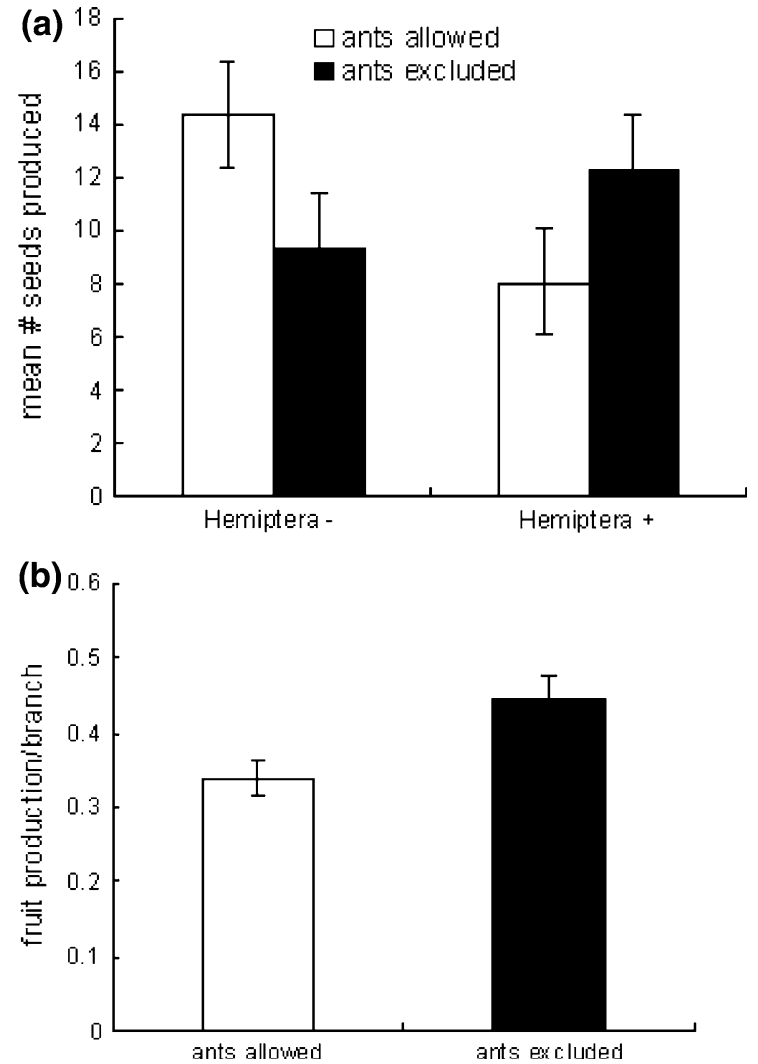

Fig. 4 Effect of ant exclusion on plant reproduction for a L. leucocephala, and $\mathbf{b} S$. taccada. See Table 2 for results of the ANOVA

increases in plant growth and fruit production. Infestations of the introduced I. seychellarum on the native $S$. taccada on Aldabra Atoll likewise resulted in decreases in leaf size, stem production, and the numbers of flowers and fruits (Newbery 1980), but excluding ants failed to reduce scale populations most likely because of the absence of effective scale predators (Hill and Blackmore 1980). Thus our current knowledge of the susceptibility of invasive and native plants to specific types of herbivores is insufficient to determine how frequently the above two conditions are met, and there are multiple specific avenues for future investigations.

Technomyrmex albipes has been shown to interfere with pollination of native Roussea simplex (Roussaceae) in Mauritius (Hansen and Müller 2009) and it is possible that the observed effects on reproductive output in this study are the result of ants directly affecting pollination. However, T. albipes were only very rarely observed on the flowers of either plant 
species and both plant species are capable of selfpollinating (Binggeli 1997; Giesen et al. 2006). For S. taccada, the observed decrease in fruit production when ants visited the trees would have required that ants decreased pollination. This is plausible if the main pollinator(s) if any, are deterred by T. albipes in the vicinity of a flower, a possibility that can only be ruled out with further detailed observations and experiments. For $L$. leucocephala, the observed effects on seed production would have required that $T$. albipes increased pollination relative to antexcluded trees when scales were absent but decreased pollination relative to ant-excluded trees when scales were present. Assuming the same pollinator, if any, pollinated $L$. leucocephala trees with and without scale insects, it is difficult to imagine a mechanism by which T. albipes could interact with the pollinator to both increase and decrease pollination of the same plant species. Thus, on L. leuocephala, we believe that it is more likely that the ants indirectly affected plant reproduction via their direct effects on herbivores.

Ant diets are influenced by both the availability and digestibility of food resources (Blüthgen and Feldhaar 2010). Stable isotope analysis of Formica podzolica ants in a temperate forest revealed a similar difference in trophic levels as observed here as ants shifted from consuming a mixture of herbivores, predators, and honeydew to a diet of primarily herbivores and honeydew over the course of the summer (Mooney and Tillberg 2005). In the present study, primarily carbohydrate-based hemipteran exudates were simultaneously available on both plants, with abundant sticky exudate from psyllids on L. leucocephala and honeydew from the sap-sucking hemipterans on $S$. taccada. Likewise, prey items appeared readily available on both plants: sedentary and abundant hemipterans on S. taccada and more mobile psyllids on L. leucocephala. The difference in T. albipes trophic level on the two plants, however, indicates that $T$. albipes preyed more heavily on herbivores on L. leucocephala and ingested more plant-based nitrogen resources from $S$. taccada. These choices may reflect preferences based on poor potential nutritional benefit, digestibility, and/ or chemical deterrents in the unharvested putative food resource. For example, in the Australian rainforests, Technomyrmex sp. (identified as albipes, but likely to be dificilis based on Bolton 2007) prefers some sugars over others and solutions containing amino acids to those with just sugars (Blüthgen and Fiedler 2004).

The monopolization of carbohydrate-based resources is thought to contribute greatly to invasive ant success (Holway et al. 2002; Kay et al. 2010; Krushelnycky et al. 2010). Carbohydrates obtained from honeydew and EFNs in our study system are likely fuelling the abundant, active T. albipes colonies on the island. Similarly, supercolony formation of Anoplolepis gracilipes and subsequent ecosystem collapse on Christmas Island is thought to be fuelled by honeydew obtained from scale insects (O'Dowd et al. 2003). A strong association between ants and carbohydrate resources may be a common factor in areas where invasive ants have reached extraordinarily high abundances (Rowles and Silverman 2009; Savage et al. 2009). Despite its potential to illuminate mechanisms of invasive ant success and impact, the quantification of ant benefits from facultative mutualisms remains an area in much need of further investigation.

Novel ecosystems and novel interactions are likely to become more prevalent with continued globalization and climate change. Recent work in a variety of ecosystems demonstrates how invasive species may fundamentally alter the food webs they invade (McNatty et al. 2009; Tillberg et al. 2007). Here we have shown how a single organism, the invasive ant T. albipes, has differing effects on an invasive and a native plant in its adopted habitat, corresponding to differences in its trophic levels on the plants. The positive effect on the invasive plant and negative effect on the native plant may ultimately work in concert to facilitate invasion by the invasive plant. We focused on mutualistic interactions in which T. albipes takes part, but like several other invasive ant species (Blancafort and Gomez 2005; Lach and Hooper-Bùi 2010), T. albipes is also capable of disrupting mutualisms, such as pollination and seed dispersal (Hansen and Müller 2009). Elucidating the myriad types and directions of novel interactions in ecosystems composed of recent arrivals and longterm residents will increase our understanding of the effects of invasive species on ecosystem function.

Acknowledgments We are grateful to Steeves Buckland and Nabiihah Roomaldawo for field assistance. We thank R. Bone, and the Mauritian Wildlife Foundation, particularly B. Vanderpaneiken, N. Armelle, I. Lenoir, A. Khadun, and V. Tatayah for logistical support. We thank S. Ganeshan at the 
Mauritius Sugar Research Institute for identifying hemipterans and beetles, and the National Parks and Conservation Service for allowing us to conduct this study on Ile aux Aigrettes. K. Abbott, D. Holway, and K. Parr provided comments on previous versions of the manuscript. This research is based upon work supported by the U.S. National Science Foundation under grant numbers 0401703 and 0516452 .

Open Access This article is distributed under the terms of the Creative Commons Attribution Noncommercial License which permits any noncommercial use, distribution, and reproduction in any medium, provided the original author(s) and source are credited.

\section{References}

Atkinson R, Sevathian JC (2005) A guide to the plants in Mauritius. Mauritian Wildlife Foundation, Vacoas

Bascompte J, Jordano P (2007) Plant-animal mutualistic networks: the architecture of biodiversity. Annu Rev Ecol Evol Syst 38:567-593

Binggeli P (1997) Leucaena leucocephala (Lam.) De Wit (Mimosaceae). http://www.bangor.ac.uk/ afs101/iwpt/ web-sp7.htm

Blancafort X, Gomez C (2005) Consequences of the Argentine ant, Linepithema humile (Mayr), invasion on pollination of Euphorbia characias (L.) (Euphorbiaceae). Acta Oecologia 28:49-55

Blüthgen N, Feldhaar H (2010) Food and shelter: how resources influence ant ecology. In: Lach L, Parr CL, Abbott KL (eds) Ant ecology. Oxford University Press, Oxford, pp 115-136

Blüthgen N, Fiedler K (2004) Preferences for sugars and amino acids and their conditionality in a diverse nectar-feeding ant community. J Anim Ecol 73:155-166

Blüthgen N, Gebauer G, Fiedler K (2003) Disentangling a rainforest food web using stable isotopes: dietary diversity in a species-rich ant community. Oecologia 137:426-435

Bolton B (2007) Taxonomy of the dolichoderine ant genus Technomyrmex Mayr (Hymenoptera: Formicidae) based on the worker cast. Contrib Am Entomol Inst 35:1-150

Boucher DH, James S, Keeler KH (1982) The ecology of mutualism. Annu Rev Ecol Syst 13:315-347

Bronstein JL (1994) Our current understanding of mutualism. Quart Rev Biol 69:31-51

Bruno JF, Stachowicz JJ, Bertness MD (2003) Inclusion of facilitation into ecological theory. Trends Ecol Evol 18:119-125

Chamberlain SA, Schlising RA (2008) Role of honey bees (Hymenoptera : Apidae) in the pollination biology of a California native plant, Triteleia laxa (Asparagales : Themidaceae). Environ Entom 37:808-816

Davidson DW, Cook SC, Snelling RR, Chua TH (2003) Explaining the abundance of ants in lowland tropical rainforest canopies. Science 300:969-972

Dietz H, Wirth LR, Buschmann H (2004) Variation in herbivore damage to invasive and native woody plant species in open forest vegetation on Mahé, Seychelles. Biol Invasions 6:511-521
Donisthorpe H (1946) The ants of Mauritius. Ann Mag Nat Hist 11:25-35

Giesen W, Wulffraat S, Zieren M, Scholten L (2006) Mangrove guidebook for southeast Asia. FAO and Wetlands International, http://www.fao.org/docrep/010/ag132e/ag 132E21.htm

Grosholz ED (2005) Recent biological invasion may hasten invasional meltdown by accelerating historical introductions. Proc Natl Acad Sci USA 102:1088-1091

Hansen DM, Müller CB (2009) Invasive ants disrupt gecko pollination and seed dispersal of the endangered plant Roussea simplex in Mauritius. Biotropica 41:202208

Hill MG, Blackmore PJM (1980) Interactions between ants and the Coccid Icerya seychellarum on Aldabra Atoll, Seychelles, Indian Ocean. Oecologia 45:360-365

Hobbs RJ, Arico S, Aronson J, Baron JS, Bridgewater P, Cramer VA, Epstein PR, Ewel JJ, Klink CA, Lugo AE, Norton D, Ojima D, Richardson DM, Sanderson EW, Valladares F, Vila M, Zamora R, Zobel M (2006) Novel ecosystems: theoretical and management aspects of the ecological world order. Glob Ecol Biogeog 15:1-7

Hollis D (1992) Leucaena psyllid, Heteropsylla cubana Crawford, newly recorded in Mauritius and Reunion. FAO Pl Prot Bull 40:49-50

Holway DA, Lach L, Suarez AV, Tsutsui ND, Case TJ (2002) The causes and consequences of ant invasions. Annu Rev Ecol Syst 33:181-233

Hughes C (2006) Leucaena leucocephala. http://www.issg.org/ database/species/ecology.asp?si=23\&fr=1\&sts

SAS Institute (1988) SAS/STAT user's guide, release 6.03. SAS Institute, Inc., Cary

Kaitaniemi P, Ruohomaki K (2006) Uncaged larvae elicit a combination of local and integrated growth responses within mountain birch crown. Oikos 115:537-548

Kay AD, Zumusch T, Heinen JL, Marsh TC, Holway DA (2010) Nutrition and interference competition have interactive effects on the behavior and performance of Argentine ants. Ecology (in press)

Koptur S (1991) Extrafloral nectaries of herbs and trees: modelling the interaction with ants and parasitoids. In: Huxley CR, Cutler DF (eds) Ant-plant interactions. Oxford University Press, Oxford, pp 213-229

Krushelnycky PD, Holway DA, LeBrun EG (2010) Invasion processes and causes of success. In: Lach L, Parr CL, Abbott KL (eds) Ant ecology. Oxford University Press, Oxford, pp 245-260

Lach L, Hooper-Bùi LM (2010) Consequences of ant invasions. In: Lach L, Parr CL, Abbott KL (eds) Ant ecology. Oxford University Press, Oxford, pp 261-286

Lowe S, Browne M, Boudlejas S, De Poorter M (2004) 100 of the world's worst invasive alien species. www.issg.org/ booklet.pdf

Marshall DL (1989) Integration of response to defoliation within plants of two species of Sesbania. Func Ecol 3:207-214

Mauritian Meteorological Services (2005) Monthly Climatology 1997-2003. http://metservice.intnet.mu/wclim.htm

McCutchan JH, Lewis WM, Kendall C, McGrath CC (2003) Variation in trophic shift for stable isotope ratios of carbon, nitrogen, and sulfur. Oikos 102:378-390 
McNatty A, Abbott KL, Lester PJ (2009) Invasive ants compete with and modify the trophic ecology of hermit crabs on tropical islands. Oecologia 160:187-194

Mooney KA, Tillberg CV (2005) Temporal and spatial variation to ant omnivory in pine forests. Ecology 86:1225-1235

Ness JH, Bronstein JL (2004) The effects of invasive ants on prospective ant mutualists. Biol Invasions 6:445461

Newbery DMC (1980) Interactions between the coccid, Icerya seychellarum (Westw.) and its host tree species on Aldabra Atoll. Oecologia 46:180-185

O'Dowd DJ, Green PT, Lake PS (2003) Invasional 'meltdown' on an oceanic island. Ecol Lett 6:812-817

Parker JD, Burkepile DE, Hay ME (2006) Opposing effects of native and exotic herbivores on plant invasions. Science 311:1459-1461

Parnell JAN, Cronk Q, Jackson PW, Strahm W (1989) A study of the ecological history of vegetation and conservation management of Ile Aux Aigrettes Mauritius Indian Ocean. J Trop Ecol 5:355-374

Post D (2007) Using stable isotopes to estimate trophic position: models, methods, and assumptions. Ecology 83:703-718

Rowles A, Silverman J (2009) Carbohydrate supply limits invasion of natural communities by Argentine ants. Oecologia 161:161-171
Savage AM, Rudgers JA, Whitney KD (2009) Elevated dominance of extrafloral nectary-bearing plants is associated with increased abundances of an invasive ant and reduced native ant richness. Div Distr 15:751-761

Simberloff D (2006) Invasional meltdown 6 years later: important phenomenon, unfortunate metaphor, or both? Ecol Lett 9:912-919

Simberloff D, Von Holle B (1999) Positive interactions of nonindigenous species: invasional meltdown? Biol Invasions $1: 21-32$

Sipura M (2002) Contrasting effects of ants on the herbivory and growth of two willow species. Ecology 83:2680-2690

Styrsky JD, Eubanks MD (2007) Ecological consequences of interactions between ants and honeydew-producing insects. Proc Roy Soc B 274:151-164

Thieltges DW (2005) Benefit from an invader: American slipper limpet Crepidula fornicata reduces star fish predation on basibiont European mussels. Hydrobiologia 541:241-244

Tillberg CV, Holway DA, LeBrun EG, Suarez AV (2007) Trophic ecology of invasive Argentine ants in their native and introduced ranges. Proc Nat Acad Sci USA 104:2085620861 